Received

April 01, 2020

Revised

June 04, 2020

Accepted

June 08, 2020

Published

July 10, 2020

*Corresponding author Otitoloju Kekere

E-mail

otito.kekere@aaua.edu.ng

Phone

$+2348067646215$

Keywords

Abattoir wastewater

Fertilizer

Organic waste

Slaughterhouses

Vegetable production

How to cite

Kekere O, Babatunde AF,

Akinbuwa O. Assessment of

growth, yield and fruit

nutritional composition to

tomato and sweet pepper

irrigated with abattoir

wastewater. Sci Lett 2020;

$8(2): 69-77$

\section{Assessment of Growth, Yield and Fruit Nutritional Composition of Tomato and Sweet Pepper Irrigated with Abattoir Wastewater}

\author{
Otitoloju Kekere*, Agnes Funmilayo Babatunde, Olumakinde \\ Akinbuwa \\ Department of Plant Science and Biotechnology, Adekunle Ajasin University, Akungba- \\ Akoko, Ondo State, Nigeria
}

\begin{abstract}
Recycling of organic-based wastewater for crop production has received worldwide acceptability as a promising alternative to fertilizer use. Hence, this research evaluated growth, yield and nutritional quality of tomato and sweet pepper irrigated with abattoir wastewater (AWW) with the aim of assessing recycling liquid effluent from slaughterhouses for crop production. Each vegetable was cultivated in experimental pots irrigated with 0 (control), 20, 40, 60, 80 and 100\% AWW. In tomato, AWW improved plant height, number of branches and leaves, and relative growth rate (RGR) with the maximum values recorded at $100 \%$ AWW. Root and shoot dry mass, total biomass and root/shoot ratio were also increased in plants treated with undiluted AWW. In sweet pepper, values of plant height, number of leaves and branches, root length and RGR were higher under AWW treatments than the control with peak values recorded at $100 \%$ concentration. The root mass of sweet pepper was increased but the root/shoot ratio was reduced at all AWW concentrations with the highest impact found when AWW was not diluted. While AWW resulted in an increased number of fruits in both crops with the best performance when undiluted, the differences with control were only significant in tomato. Fresh and dry mass of fruit was also significantly increased by AWW in both crops with the highest values recorded at $100 \%$ concentration. AWW increased fruit nutrient and heavy metal contents of both vegetables but this increase was nonsignificant compared to control. In conclusion, the application of $20-80 \%$ AWW is capable of increasing tomato and sweet pepper production but growing them with undiluted AWW irrigation was the most effective alternative source of fertilizers for improved growth, yield and nutritional quality of vegetables.
\end{abstract}

This work is licensed under the Creative Commons Attribution-NonCommercial 4.0 International License. 


\section{Introduction}

Tomato (Lycopersicum esculentum L.) is a vegetable crop grown worldwide, which ranks third in global vegetable production [1]. Its global production, which was over 159 million tons in 2011 [2] dropped to 27.3 metric tons, according to the Global Tomato Industry Report in 2018, and 37.5 million metric tons in 2019 [3]. Over $80 \%$ of tomatoes grown throughout the world are processed into a variety of products for consumption [4]. Similarly, sweet pepper (Capsicum annum L.) is a vegetable with high nutritive value occupying an important position in daily diets in Sub-Saharan Africa. Nigeria is one of the major producers in the world accounting for about $50 \%$ of African production [5]. The meat-processing industry uses about $35 \%$ to $40 \%$ of world production and it is the spice mostly used on Nigerian dishes [6]. In recent times, the production of vegetables has not been able to meet demand by the growing human population. [6, 7]. For example, it was reported by the Horticultural Institute of Nigeria in 2017 that tomato national production stands at 2.3 metric tons as against 3 million metric tons of national demand. The yield reduction due to soil infertility has been a major factor thus bringing about serious concerns of many small-scale African farmers [6, 7]. Although chemical fertilizers can improve crop yield, they are most often not readily available and expensive [8]. This has brought about increased advocacy for alternative sources of nutrients in infertile soils such as recycling of organic-based wastewater for crop production [1, 9-17].

Slaughterhouses are an important component of meat for the common people and meat processing industry that produce large volumes of abattoir wastewater (AWW) from the cleaning of slaughterhouses and facilities [18-22]. The total amount of waste produced per animal slaughtered is approximately $35 \%$ of its weight [23]. This is usually released in large quantities directly into the ecosystems without adequate treatment process [2425]. In addition, it is not uncommon to locate abattoirs near aquatic environments to ensure water availability; hence the wastes generated are discharged into the water bodies [26-28]. According to Omole and Longe [29], AWW could increase the level of nitrogen, phosphorus and total solids in receiving water bodies, which could encourage the rapid growth of algae leading to eutrophication. It is a rich source of nutrients even after primary treatment [30]. In comparison with other wastewater sources, AWW possesses the highest concentration of organic load, with a high volume of COD $(8000 \mathrm{mg} / \mathrm{L})$, proteins $(70 \%)$ and suspended solids of $15-30 \mathrm{mg} / \mathrm{L}$ [31]. Masse and Masse [32] stated that AWW can act as a source of major nutrients ( $\mathrm{N}$ and $\mathrm{P}$ ) and micronutrients such as calcium, sodium, magnesium, sulfur and iron. Irrigation with wastewater is a potential low-cost approach to wastewater management and a good source of nutrients for infertile soils [33-34]. Castrol et al. [35] also stated that irrigation with AWW had positive impacts on plant growth and development. Sparling et al. [36] observed that AWW irrigation significantly increased the annual and total herbage production. Roy et al. [37] recorded a significant increase in plant height, number of leaves, leaf area, number of fruits, number of flowers and total fruit weight of plants grown in soil added with slaughterhouse wastes.

Discharge of untreated AWW has been widely reported to bring about surface water contamination, general environmental pollution and public health concerns [38-43]. As such, most research on it has focused largely on their characteristics and associated public health concerns [18-19, 21, 41-44]. There is not enough data available regarding plant responses to different concentrations or levels of AWW. Besides, vegetables like tomato and sweet pepper are grown largely in-home gardens in South-Western Nigeria have a high possibility of having direct contact with wastewater from abattoirs situated near residential areas or from runoff of those disposed of in gullies. Hence, the aim of this research was to assess growth, yield and fruit nutritional quality of tomato and sweet pepper, which are important vegetables in high demand for daily diets in Nigeria. We hypothesized that recycling it for crop production might produce positive results, which could enhance sustainable management of the effluent and contribute to food security.

\section{Materials and Methods}

It was a screenhouse research carried out from March to April 2019 at the Plant Science and Biotechnology Department, Adekunle Ajasin University, Akungba Akoko, Ondo State, Nigeria (latitude $7^{\circ} 37^{\mathrm{i}} \mathrm{N}$ and longitude $5^{\circ} 44 \mathrm{E}$ ). Seedlings of locally grown tomato and sweet pepper were raised separately in perforated polyethylene pots $(15 \mathrm{~cm}$ diameter $\times 12 \mathrm{~cm}$ height) filled with $5 \mathrm{~kg}$ soil with pre-determined physicochemical parameters [45]. The AWW used for this experiment was obtained 
from slaughterhouses at different locations in Akungba-Akoko, Ondo State, Nigeria. The wastewaters were thoroughly mixed and some characteristics determined following the standard procedure of AOAC [46]. The data are shown in Table 1. Concentrations of 20, 40, 60, 80 and $100 \%$ AWW were prepared in plastic kegs just before each treatment by dilution with tap water to make the desired concentrations while the tap water without AWW served as the control $(0 \%$ concentration). Seedlings in each pot were thinned to remain one per pot in such a way that the seedlings for each vegetable were of relatively equal size and treatments commenced at one month after planting. Each pot was irrigated with $250 \mathrm{ml}$ (volume enough to keep the soil moist) 3 times in a week. Pots were laid out in a completely randomized design (CRD) with 5 single-plant replicates per treatment. The tomato was treated for 9 weeks and sweet pepper for 12 weeks before the experiment was terminated due to different maturity time.

Plant height and root length were measured by meter rule, and stem girth with a digital Vernier caliper (model $0-200 \mathrm{~mm}$ ) at the $5 \mathrm{~cm}$ point from the stem base. The leaves and branches produced were manually counted. Fruits and other plant parts were measured for fresh weight before oven-drying to constant weight for dry mass determination with Metler PC 180 weighing balance. The root dry mass was divided by that of the shoot to get root/shoot ratio. Dried fruit samples were digested using $10 \mathrm{ml}$ of $20 \%$ sulfuric acid. $\mathrm{Na}^{+}$and $\mathrm{K}^{+}$were analyzed by

Table 1 Some characteristics of the abattoir wastewater used for the experiment.

\begin{tabular}{ll}
\hline Parameters & Value \\
\hline BOD $(\mathrm{mg} / \mathrm{l})$ & 647.62 \\
COD $(\mathrm{mg} / \mathrm{l})$ & 1187.65 \\
Cond $\left(\mu \mathrm{s} \mathrm{cm}{ }^{-1}\right)$ & 320 \\
pH & 8.0 \\
TDS $(\mathrm{mg} / \mathrm{L})$ & 3224 \\
Temperature $\left({ }^{0} \mathrm{C}\right)$ & 27.7 \\
TOC $(\mathrm{mg} / \mathrm{l})$ & 1342 \\
TSS $(\mathrm{mg} / \mathrm{l})$ & 910 \\
Turbidity $(\mathrm{VTU})$ & 252 \\
$\mathrm{~K}(\mathrm{mg} / \mathrm{l})$ & 1.27 \\
Nitrate $(\mathrm{mg} / \mathrm{l})$ & 36 \\
Phosphate $(\mathrm{mg} / \mathrm{l})$ & 17 \\
Sulphate $(\mathrm{mg} / \mathrm{l})$ & 49 \\
$\mathrm{Cr}(\mathrm{mg} / \mathrm{l})$ & 0.19 \\
Cu $(\mathrm{mg} / \mathrm{l})$ & 0.19 \\
$\mathrm{~Pb}(\mathrm{mg} / \mathrm{l})$ & 0.29 \\
$\mathrm{Zn}(\mathrm{mg} / \mathrm{l})$ & 0.22 \\
\hline
\end{tabular}

flame photometry while $\mathrm{Mg}^{2+}$ and $\mathrm{Ca}^{2+}$ were by EDTA titration method [46]. $\mathrm{Cu}, \mathrm{Zn}, \mathrm{Pb}$ and $\mathrm{Cr}$ were assayed by the atomic absorption spectrophotometer (Buck 210). Phosphorous was determined calorimetrically using Spectronic 20 (Gallenkemp, UK) while crude protein, lipid, carbohydrate, fiber and ash contents of the dry tomato and sweet pepper fruit powders were determined using the standard laboratory procedures provided by AOAC [46]. Data were subjected to one-way ANOVA and means were separated with the Tukey HSD Test at the $5 \%$ level of probability using SPSS ver. 24.0 statistical software (SPSS, Chicago, IL).

\section{Results}

Tomato plants grown in soil irrigated with AWW had improved growth over the ones irrigated with water devoid of AWW (Table 2). Statistical analysis revealed that the plant height differed significantly compared to control $(68.2 \mathrm{~cm})$ at $40-$ $100 \%$ concentrations of AWW (87.3-97.3 cm) but it was highest at $100 \%$ concentration $(97.30 \mathrm{~cm})$. Likewise, the number of branches and relative growth rate $(22.7$ and $0.014 \mathrm{~g} / \mathrm{g}$ dry weight, respectively) differed significantly at $60-100 \%$ concentrations of AWW compared to control (34.739.0 and $0.02-0.08 \mathrm{~g} / \mathrm{g}$ dry weight respectively) with the best performance when treated with undiluted AWW. The number of leaves significantly differed from the control $(126.8 \mathrm{~cm})$ at $80-100 \%$ concentrations of AWW (172-182) with the maximum value recorded at $100 \%$ concentration. No significant differences were; however, obtained in stem girth and root length between the control and AWW-treated tomato plants. Similarly, sweet pepper grown under AWW irrigation had root length and relative growth rate that increased significantly at all treatment levels (5.1-8.5 cm and 0.042-0.046 g/g dry weight, respectively) compared to their respective control with peak valued obtained under undiluted AWW $(100 \%)$. The increase in plant height, number of leaves and number of branches were highest at $100 \%$ concentrations (66 cm, 104.7 and 13.7, respectively) in comparison to their respective control and other treatments. Only the stem girth did not show any significant difference among different treatments in sweet pepper (Table 2). The results showed that dry mass of above- and below-ground plant parts as well as total biomass were increased by the different concentrations of AWW applied to both plants (Table 3). In tomato, root and shoot dry 
Science Letters 2020; 8(2):69-77

Table 2 Impact of abattoir wastewater irrigation on some growth parameters of tomato and sweet pepper.

\begin{tabular}{|c|c|c|c|c|c|c|c|}
\hline \multirow{2}{*}{ Plant species } & \multirow{2}{*}{ Growth parameter } & \multicolumn{6}{|c|}{ Quantity of abattoir wastewater applied (\%) } \\
\hline & & $\mathbf{0}$ & 20 & 40 & 60 & 80 & 100 \\
\hline \multirow{6}{*}{ Tomato } & Plant height $(\mathrm{cm})$ & $68.17^{\mathrm{b}}$ & $78.70^{\mathrm{ab}}$ & $91.73^{\mathrm{a}}$ & $95.93^{\mathrm{a}}$ & $94.83^{\mathrm{a}}$ & $97.30^{\mathrm{a}}$ \\
\hline & Number of leaves & $126.67^{\mathrm{b}}$ & $120.67^{b}$ & $121.33^{\mathrm{b}}$ & $132.33^{\mathrm{ab}}$ & $175.30^{\mathrm{a}}$ & $182.00^{\mathrm{a}}$ \\
\hline & Number of branches & $22.67^{\mathrm{b}}$ & $28.67^{\mathrm{ab}}$ & $29.67^{\mathrm{ab}}$ & $34.67^{\mathrm{a}}$ & $35.33^{\mathrm{a}}$ & $39.00^{\mathrm{a}}$ \\
\hline & Stem girth $(\mathrm{cm})$ & 8.92 & 9.13 & 9.82 & 9.82 & 10.34 & 10.46 \\
\hline & Root length (cm) & 6.52 & 8.78 & 10.56 & 10.78 & 10.67 & 10.89 \\
\hline & Relative growth rate (g/g dry weight) & $0.014^{\mathrm{c}}$ & $0.015^{\mathrm{c}}$ & $0.016^{\mathrm{c}}$ & $0.020^{\mathrm{b}}$ & $0.022^{\mathrm{b}}$ & $0.08^{\mathrm{a}}$ \\
\hline \multirow{6}{*}{ Sweet pepper } & Plant height $(\mathrm{cm})$ & $30.20^{\mathrm{b}}$ & $56.25^{\mathrm{ab}}$ & $47.30^{\mathrm{ab}}$ & $45.03^{\mathrm{ab}}$ & $52.60^{\mathrm{ab}}$ & $66.00^{\mathrm{a}}$ \\
\hline & Number of leaves & $57.00^{\mathrm{b}}$ & $61.33^{\mathrm{b}}$ & $50.33^{\mathrm{b}}$ & $54.67^{b}$ & $62.00^{\mathrm{b}}$ & $104.67^{\mathrm{a}}$ \\
\hline & Number of branches & $7.00^{\mathrm{b}}$ & $7.67^{\mathrm{b}}$ & $7.00^{\mathrm{b}}$ & $6.33^{\mathrm{b}}$ & $10.00^{\mathrm{ab}}$ & $13.67^{\mathrm{a}}$ \\
\hline & Stem girth $(\mathrm{cm})$ & 5.08 & 6.33 & 5.15 & 5.66 & 6.71 & 6.90 \\
\hline & Root length (cm) & $3.45^{\mathrm{b}}$ & $6.26^{\mathrm{b}}$ & $5.10^{\mathrm{a}}$ & $7.18^{\mathrm{a}}$ & $8.20^{\mathrm{a}}$ & $8.47^{\mathrm{a}}$ \\
\hline & Relative growth rate (g/g dry weight) & $0.030^{\mathrm{b}}$ & $0.045^{\mathrm{a}}$ & $0.046^{\mathrm{a}}$ & $0.042^{\mathrm{a}}$ & $0.043^{\mathrm{a}}$ & $0.043^{\mathrm{a}}$ \\
\hline
\end{tabular}

Each value is a mean \pm S.E of 5 replicates. For each value, means with the different letter(s) in superscript on the same row are significantly different at $P \geq 0.05$ (Tukey HSD test).

Table 3 Impact of abattoir wastewater irrigation on dry mass and root/shoot ratio of tomato and sweet pepper.

\begin{tabular}{|c|c|c|c|c|c|c|c|}
\hline \multirow{2}{*}{ Plant species } & \multirow{2}{*}{ Dry matter } & \multicolumn{6}{|c|}{ Quantity of abattoir wastewater applied (\%) } \\
\hline & & $\mathbf{0}$ & 20 & 40 & 60 & 80 & 100 \\
\hline \multirow{4}{*}{ Tomato } & Root dry mass (g) & $0.30^{\mathrm{bc}}$ & $0.43^{\mathrm{b}}$ & $0.60^{\mathrm{b}}$ & $1.23^{\mathrm{a}}$ & $1.20^{\mathrm{a}}$ & $1.37^{\mathrm{a}}$ \\
\hline & Shoot dry mass (g) & 3.57 & 5.00 & 5.73 & 7.67 & 8.23 & 8.30 \\
\hline & Total biomass $(\mathrm{g})$ & $3.89^{\mathrm{b}}$ & $5.42^{\mathrm{ab}}$ & $6.35^{\mathrm{ab}}$ & $8.89^{\mathrm{a}}$ & $9.48^{\mathrm{a}}$ & $9.55^{\mathrm{a}}$ \\
\hline & Root/shoot ratio & $0.08^{\mathrm{ab}}$ & $0.09^{\mathrm{ab}}$ & $0.10^{\mathrm{ab}}$ & $0.16^{\mathrm{a}}$ & $0.15^{\mathrm{a}}$ & $0.17^{\mathrm{a}}$ \\
\hline \multirow{4}{*}{ Sweet pepper } & Root dry mass (g) & $1.33^{\mathrm{b}}$ & $2.77^{\mathrm{a}}$ & $2.23^{\mathrm{a}}$ & $2.77^{\mathrm{a}}$ & $2.50^{\mathrm{a}}$ & $2.97^{\mathrm{a}}$ \\
\hline & Shoot dry mass (g) & $1.8^{\mathrm{c}}$ & $3.50^{\mathrm{bc}}$ & $3.61^{\mathrm{bc}}$ & $5.40^{\mathrm{b}}$ & $10.40^{\mathrm{a}}$ & $10.77^{a}$ \\
\hline & Total biomass (g) & $3.33^{\mathrm{c}}$ & $6.26^{\mathrm{bc}}$ & $5.80^{\mathrm{bc}}$ & $8.19^{\mathrm{b}}$ & $13.40^{\mathrm{a}}$ & $13.74^{\circ}$ \\
\hline & Root/shoot ratio & $0.74^{\mathrm{b}}$ & $0.79^{\mathrm{b}}$ & $0.62^{\mathrm{b}}$ & $0.33^{\mathrm{a}}$ & $0.23^{\mathrm{a}}$ & $0.27^{\mathrm{a}}$ \\
\hline
\end{tabular}

Each value is a mean \pm S.E of 5 replicates. For each value, means with the different letter(s) in superscript on the same row are significantly different at $P \geq 0.05$ (Tukey HSD test).

mass as well as total biomass and root/shoot ratio increased at a significant level under $60-100 \%$ concentrations of AWW (1.2-1.4, 7.7-8.3 and 8.9$9.5 \mathrm{~g}$, respectively) in comparison to their respective control treatments $(0.3,3.6$ and $3.9 \mathrm{~g}$, respectively), while the shoot dry mass was not significantly affected by AWW treatments. It was; however, found that the best performance occurred in plants irrigated with undiluted AWW. On the other hand, sweet pepper root dry mass increased significantly when treated with AWW (2.23-2.97 g) while the root / shoot ratio was found to be reduced significantly in comparison with the control (0.74) at $60-100 \%$ concentrations of AWW (0.27-0.33). It was; however, obvious that the performance was better under $100 \%$ AWW concentration.

From the results presented in Table 4, it was revealed that the application of AWW improved yield in both vegetables. Irrigation of tomato with AWW had no significant effect on the number of fruits produced per plant with 4.33 fruits in the control and 5.00-7.33 under AWW treatments. AWW application; however, significantly increased the fruit fresh (20.6-36.8 g) and dry mass (4.4-7.9 g) relative to the control (13.7 and $2.2 \mathrm{~g}$, respectively).
In sweet pepper, on the other hand, the number of fruits per plant (3.3-8.2), fruit fresh (7.4-15.8 g) and dry mass (2.5-7.3 g) were significantly increased over the control (1.1, 2.6 and $1.1 \mathrm{~g}$, respectively). Summarily, the overall yield performance was best in plants irrigated with undiluted AWW. Table 5 shows that the fruits produced by tomato and sweet pepper plants treated with different concentrations of AWW had all the nutritional and proximate parameters with higher values than in the control. However, no statistical differences were found when comparisons were made between each of the nutritional and proximate parameters under AWW and the control treatments. Table 6 shows an increased concentration of heavy metals $(\mathrm{Cu}, \mathrm{Zn}$ and $\mathrm{Pb}$ ) in the fruits of plants grown with AWW irrigation while that of $\mathrm{Cr}$ was not influenced by AWW application relative to the control treatment. Statistical analysis; however, revealed that even where differences were recorded between the control and AWW-treated plants, the differences were not significant. $\mathrm{Cu}, \mathrm{Zn}, \mathrm{Pb}$ and $\mathrm{Cr}$ were 0.18 , $0.37,0.29$ and $0.04 \%$, respectively in the control but ranged $0.20-1.24,0.82-0.83,0.41-0.54$ and $0.02-$ $0.05 \%$, respectively under AWW treatments. 
Table 4 Impact of abattoir wastewater irrigation on some yield parameters of tomato and sweet pepper.

\begin{tabular}{|c|c|c|c|c|c|c|c|}
\hline \multirow{2}{*}{ Plant species } & \multirow{2}{*}{ Yield parameters } & \multicolumn{6}{|c|}{ Quantity of abattoir wastewater applied (\%) } \\
\hline & & $\mathbf{0}$ & 20 & 40 & 60 & 80 & 100 \\
\hline \multirow{3}{*}{ Tomato } & Number of fruits/plant & 4.33 & 6.00 & 5.00 & 5.33 & 6.33 & 7.33 \\
\hline & Fruit fresh mass $(\mathrm{g})$ & $13.70^{\mathrm{b}}$ & $31.38^{\mathrm{a}}$ & $20.63^{\mathrm{a}}$ & $26.23^{\mathrm{a}}$ & $29.07^{\mathrm{a}}$ & $36.83^{\mathrm{a}}$ \\
\hline & Fruit dry mass (g) & $2.20^{\mathrm{b}}$ & $7.20^{\mathrm{a}}$ & $7.90^{\mathrm{a}}$ & $6.57^{\mathrm{a}}$ & $4.40^{\mathrm{a}}$ & $4.97^{\mathrm{a}}$ \\
\hline \multirow{3}{*}{ Sweet pepper } & Number of fruits/plant & $1.10^{\mathrm{c}}$ & $3.33^{\mathrm{ab}}$ & $3.50^{\mathrm{ab}}$ & $6.89^{\mathrm{a}}$ & $7.33^{\mathrm{a}}$ & $8.23^{\mathrm{a}}$ \\
\hline & Fruit fresh mass $(\mathrm{g})$ & $2.56^{\mathrm{c}}$ & $7.47^{\mathrm{b}}$ & $8.60^{\mathrm{b}}$ & $10.98^{\mathrm{b}}$ & $15.87^{\mathrm{a}}$ & $19.75^{a}$ \\
\hline & Fruit dry mass (g) & $1.12^{\mathrm{c}}$ & $2.53^{\mathrm{b}}$ & $3.67^{b}$ & $4.13^{\mathrm{b}}$ & $7.27^{\mathrm{ab}}$ & $13.87^{\mathrm{a}}$ \\
\hline
\end{tabular}

Each value is a mean \pm S.E of 5 replicates. For each value, means with the different letter(s) in superscript on the same row are significantly different at $P \geq 0.05$ (Tukey HSD test).

Table 5 Impact of abattoir wastewater irrigation on fruit proximate and nutritional composition of tomato and sweet pepper.

\begin{tabular}{|c|c|c|c|c|c|c|c|}
\hline \multirow{2}{*}{ Plant species } & \multirow{2}{*}{$\begin{array}{c}\text { Nutritional and proximate } \\
\text { composition }(\%)\end{array}$} & \multicolumn{6}{|c|}{ Quantity of abattoir wastewater applied (\%) } \\
\hline & & $\mathbf{0}$ & 20 & 40 & 60 & 80 & 100 \\
\hline \multirow{11}{*}{ Tomato } & $\mathrm{N}$ & 1.38 & 1.49 & 1.61 & 1.63 & 1.87 & 1.91 \\
\hline & $\mathrm{P}$ & 0.04 & 0.06 & 0.10 & 0.09 & 0.17 & 0.19 \\
\hline & $\mathrm{K}$ & 0.67 & 1.02 & 0.85 & 0.96 & 1.21 & 1.32 \\
\hline & $\mathrm{Ca}$ & 0.16 & 0.23 & 0.21 & 0.23 & 0.24 & 0.23 \\
\hline & $\mathrm{Mg}$ & 0.23 & 0.18 & 0.18 & 0.34 & 0.47 & 0.32 \\
\hline & $\mathrm{Na}$ & 0.21 & 0.24 & 0.27 & 0.27 & 0.29 & 0.30 \\
\hline & Ash & 0.69 & 0.85 & 0.83 & 0.87 & 0.97 & 0.52 \\
\hline & Fiber & 1.27 & 1.29 & 1.35 & 1.31 & 1.29 & 1.32 \\
\hline & Protein & 8.31 & 9.31 & 10.06 & 10.19 & 11.69 & 9.88 \\
\hline & Lipid & 0.94 & 0.94 & 0.86 & 0.93 & 0.91 & 0.89 \\
\hline & Nitrogen free extract & 8.60 & 7.73 & 7.10 & 7.90 & 8.24 & 8.60 \\
\hline \multirow{11}{*}{ Sweet pepper } & $\mathrm{N}$ & 0.48 & 0.53 & 0.52 & 0.65 & 0.79 & 0.77 \\
\hline & $\mathrm{P}$ & 0.07 & $0.08^{\mathrm{a}}$ & 0.08 & 0.07 & 0.10 & 0.13 \\
\hline & $\mathrm{K}$ & 0.63 & 0.91 & 0.90 & 0.95 & 0.95 & 0.94 \\
\hline & $\mathrm{Ca}$ & 0.43 & 0.47 & 0.49 & 0.71 & 0.77 & 0.75 \\
\hline & $\mathrm{Mg}$ & 0.16 & 0.19 & 0.21 & 0.24 & 0.33 & 0.31 \\
\hline & $\mathrm{Na}$ & 0.19 & 0.24 & 0.33 & 0.37 & 0.42 & 0.47 \\
\hline & Ash & 4.59 & 4.63 & 4.65 & 4.71 & 5.32 & 5.44 \\
\hline & Fiber & 9.98 & 10.46 & 10.78 & 10.55 & 10.49 & 10.59 \\
\hline & Protein & 0.30 & 0.32 & 0.30 & 0.39 & 0.39 & 0.37 \\
\hline & Lipid & 1.79 & 1.82 & 1.94 & 1.93 & 2.00 & 2.00 \\
\hline & Nitrogen free extract & 0.68 & 0.71 & 0.77 & 0.80 & 0.79 & 0.80 \\
\hline
\end{tabular}

Each value is a mean \pm S.E of 3 replicates. For each value, means with the different letter(s) in superscript on the same row are significantly different at $P \geq 0.05$ (Tukey HSD test).

\section{Discussion}

This study revealed that all concentrations of the wastewater generally enhanced the growth parameters of the two vegetables. This result is in conformity with the ones obtained from experiments conducted on Solanum lycopersicum, Solanum melongena and Capsicum annuum by Roy et al. [37]. They found a significant increase in plant height, number of leaves, leaf area, number of fruits, number of flowers and total fruit weight of plants grown in soil mixed with slaughterhouse wastes used as organic fertilizer. It also agrees with research on Pennisetum purpureum, Sinapis alba, Helianthus annus and Medicago sativa where plant growth was improved by abattoir wastewater [15]. Similarly, Castrol et al. [35] also reported that AWW irrigation had positive impacts on plant growth and development. Growth improvement can be attributed to an increase in soil fertility following AWW application as confirmed by Matheyarasu and Bolan [47] who applied AWW to low-fertility soils and found an increase in soil fertility status. The presence of essential nutrients for plant growth in the AWW used for this study (Table 1) must have increased soil fertility, thereby bringing about better growth than in the control. This experiment also revealed that AWW enhanced the root and shoot dry masses as well as the total biomass of both plants. In a previous study, Nissim et al. [48] showed that irrigation with municipal wastewater had a positive effect on willow growth and biomass yield. Likewise, Misra et al. [10] observed that Solanum lycoperscum irrigated with domestic wastewater obtained higher nutrient uptake and biomass at the flowering stage when compared to 
tap water. Gupta et al. [13] reported that plants irrigated with domestic wastewater resulted in a significant increase in biomass and green fodder yield of sorghum as compared to well water. Zema et al. [12] investigated the biomass yield of Typha latifolia and found it to be increased by irrigation with urban wastewater.

In this study, apart from the biomass, fruit yield of the vegetables was improved by AWW particularly at $100 \%$ concentration relative to other treatments. This concurs with the previous study of Bedbabis et al. [14] that municipal wastewater irrigation of olive trees resulted in significant yield increase when compared to yields from the plot using well water. Qaryouti et al. [1] concluded that the irrigation using raw wastewater from food industry increased significantly tomato growth and yield parameters, as well as cucumber plant height and fruit yield. Day et al. [9] also compared the effect of irrigation with municipal wastewater and pump water on wheat. They discovered that wastewater irrigation produced taller plants, heavier seeds and higher grain yields than pump water. Similar results were also recorded by Juwarkar et al. [49] on Arachis hypogaea. Furthermore, yield improvement in plants grown in wastewater treated soil conforms to that of Matheyarasu and Bolan [47] who found about 70\% lower yields in Pennisetum purpureum, Medicago sativa, Sinapis alba and Helianthus annuus grown under tap water compared to the abattoir wastewater irrigation. Similarly, in a pot experiment, fertilizer produced from abattoir waste products was found to significantly increase biomass yield of AberMagic grass (Lolium perenne) and wheat (Triticum aestivum) compared with the Nil treatment pots [17]. They reported more grain production in wheat and AberMagic grass when AWW was applied and concluded that it is a sustainable alternative to conventional fertilizers. Yield improvement could be linked to an increase in the number of leaves that provided more surface area for photosynthetic activities, which produced more photosynthates for fruit production. $\mathrm{Mg}$ in the wastewater is an integral part of chlorophyll, which when absorbed by plants could enhance chlorophyll synthesis which is a factor in yield production.

This study also revealed increased fruit nutritional composition in both plants at all levels of AWW when compared with the control. Similarly, Al-Jaloud et al. [50] reported raised levels of $\mathrm{N}, \mathrm{Ca}, \mathrm{Mg}$ and $\mathrm{Na}$ in leaves of sorghum when the crop was irrigated with domestic wastewater. Moreover, Vasquez-Montiel et al. [11] found that irrigation of maize (Zea mays L.) with treated domestic wastewater resulted in increased $\mathrm{N}, \mathrm{P}, \mathrm{K}$ and $\mathrm{Mg}$ concentration in the leaves. Fonseca et al. [51] reported similar results in a greenhouse experiment on AWW on maize. In a previous study, concentrations of nutrients, including $\mathrm{N}, \mathrm{P}, \mathrm{K}, \mathrm{Ca}, \mathrm{Mg}$ and $\mathrm{Na}$ were found higher in Lolium perenne and Triticum aestivum grown in soil treated with fertilizer produced from abattoir wastes [17]. Also, Matheyarasu and Bolan [47] reported the application of AWW to cause an abundance of nutrient accumulation in Pennisetum purpureum, Medicago sativa, Sinapis alba and Helianthus annuus. The increase in the nutrients is as a result of their increased concentration in the soil with AWW.

Increase in proximate composition as a result of AWW treatment in this study is in agreement with that of Babyshakila et al. [52] who recorded higher lipid, ash and protein content at 50\% and $75 \%$ concentrations of AWW in the leaf samples of mung bean compared to the control. Achuba and Iserhienrhien [53] also obtained more chlorophyll, $\beta$-carotene, amino acids, protein and sugar in the leaves of cowpea seedlings exposed to AWW relative to the control. The activities of $\alpha$-amylase

Table 6 Impact of abattoir wastewater irrigation on the fruit-heavy metal content of tomato and sweet pepper.

\begin{tabular}{lccccccc}
\hline \multirow{2}{*}{ Plant species } & Heavy metal & \multicolumn{5}{c}{ Quantity of abattoir wastewater applied $(\%)$} \\
\cline { 2 - 7 } concentration $(\%)$ & $\mathbf{0}$ & $\mathbf{2 0}$ & $\mathbf{4 0}$ & $\mathbf{6 0}$ & $\mathbf{8 0}$ & $\mathbf{1 0 0}$ \\
\hline \multirow{3}{*}{ Tomato } & $\mathrm{Cu}$ & 0.18 & 0.20 & 0.29 & 1.08 & 1.07 & 1.24 \\
& $\mathrm{Zn}$ & 0.37 & 0.83 & 0.82 & 1.51 & 1.65 & 1.17 \\
& $\mathrm{~Pb}$ & 0.29 & 0.41 & 0.40 & 0.42 & 0.45 & 0.54 \\
\multirow{3}{*}{ Sweet pepper } & $\mathrm{Cr}$ & 0.04 & 0.02 & 0.04 & 0.03 & 0.04 & 0.05 \\
& $\mathrm{Cu}$ & 3.97 & 4.63 & 4.91 & 4.90 & 4.99 & 4.98 \\
& $\mathrm{Zn}$ & 8.78 & 10.46 & 10.87 & 11.01 & 12.03 & 13.44 \\
& $\mathrm{~Pb}$ & 0.21 & 0.32 & 0.45 & 0.74 & 0.73 & 0.82 \\
\hline
\end{tabular}

Each value is a mean $\pm \mathrm{S}$.E of 3 replicates. For each value, means with the same letter(s) in superscript on the same row are not significantly different at $P \geq 0.05$ (Tukey HSD test). 
and starch phosphorylase in the leaves of cowpea seedlings were also observed to be increased by AWW treatments over the control [53]. It was explained by Matheyarasu and Bolan [47] that AWW application increases the population of microorganisms for improved mineralization of organic matters in the soil and some of the microorganisms play important roles in the fixation of atmospheric nitrogen. Increased nutrient availability in the soil, enhanced enzymatic and microbial activities in the presence of AWW might have contributed to improved yield and nutritional quality of the fruits. This was further confirmed by Achuba and Iserhienrhien [53] who concluded that abattoir wastewater is a good source of organic manure containing essential nutrients like nitrate and phosphate.

The increase in concentrations of heavy metals in fruits of pepper and tomato treated with AWW is in accordance with that of Masse and Masse [32] who stated that AWW can act as a source of major nutrients, micronutrients and trace amount of heavy metals. In a recent study, Darch et al. [17] found higher values of heavy metals like $\mathrm{As}, \mathrm{Cd}, \mathrm{Cr}, \mathrm{Ni}$, $\mathrm{Mo}, \mathrm{Co}, \mathrm{Fe}, \mathrm{Al}, \mathrm{Cu}$ and $\mathrm{Pb}$ in Lolium perenne and Triticum aestivum grown with fertilizer produced from abattoir wastes than in those grown without it. This could be as a result of the presence of heavy metals in wastes generated from slaughterhouses, which is evident in the results of the AWW analysis in this study (Table 1). The presence of heavy metals in wastes generated from slaughterhouses has also been confirmed by many researchers and the metals were reported to be part of metal accumulation in body tissues of animals from their feeds and also from cleaning of facilities for meat processing in slaughterhouses [20-21, 47].

\section{Conclusion}

In this study, irrigation of tomato and sweet pepper with $100 \%$ abattoir wastewater was the best treatment for their production and is, therefore, recommended as a substitute source of fertilizer for enhanced growth, yield and nutritional quality of the vegetables. Meanwhile, concentrations of 20$80 \%$ can also lead to yield improvements in the vegetables. It is recommended that abattoir wastewater should be channeled for reuse in home gardens or stored in a septic system for crop irrigation. There is; however, the need for further studies on the environmental impacts associated with AWW reuse and investigate the public acceptance of the concept.

\section{Acknowledgment}

We would like to appreciate Late Mr. Joseph Jack Udoh in the Research Laboratory of the National Institute for Oil Palm Research (NIFOR), Nigeria for his support during laboratory analyses.

\section{Conflict of Interest}

The author declares no conflict of interest in this study.

\section{References}

[1] Qaryouti M, Bani-Hani N, Abu-Sharar TM, Shnikat I, Hiari M, Radiadeh M. Effect of using raw waste water from food industry on soil fertility, cucumber and tomato growth, yield and fruit quality. Sci Hortic 2015; 193:99-104.

[2] Ministry of Food, Agriculture and Livestock (MINFAL). Agricultural Statistics of Pakistan. Ministry of Food, Agriculture, and Livestock. Food, Agriculture, and Livestock Division (Economic Wing), Islamabad. 2011.

[3] Colvine S, Branthome F. AMITOM \& WPTC: Crop situation as of May 2019, presented at the Tomato News Conference, Avignon held on 16-17 May, 2019.

[4] Viskelis P, Radzevicius A, Urbonaviciene D, Viskelis J, Karkleliene R, Bobinas C. Biochemical parameters in tomato fruits from different cultivars as functional foods for agricultural, industrial, and pharmaceutical uses. In H. El- Shemy (Ed.), In Tech Open, Plants for the Future; 2015, p. 45-77.

[5] Idowu-agida OO, Nwaguma EI, Adeoye IB. Cost implication of wet and dry season pepper production in Ibadan South western Nigeria. Agric Biol J North America 2014; 1(4):495-500.

[6] Toungus MD, Babayola M, Shehu HE, Kwaga YM, Bamai N. Effect of Nitrogen fertilizer on the growth of vegetable amanranths (Amaranthuscruensis L.) in Mubi, Adamawa State Nigeria. Asian J Adv Agric Res 2018; 6(2):1-12.

[7] Kimani SK, Nandwa SM, Mugendi DN. Principles of integrated soil fertility management. In: Soil Fertility Management in Africa: A Regional Perspective; 2003, p. 51-72.

[8] Ciceri D, Allanore A. Local fertilizers to achieve food self-sufficiency in Africa. Sci Total Environ 2019; 648:669-680.

[9] Day AD, Rahman A, Katterman FR, Jensen V. Effects of treated municipal wastewater and commercial fertilizer on growth, fibre, acid-soluble nucleotides, protein and amino acid content in wheat hay. J Environ Qual 1974; 3:17-19.

[10] Misra RK, Patel JH, Baxi VR. Removal of pollutants by tomato plants duringre-use of laundry greywater for irrigation. In: International Conference on Food Security and Environmental Sustainability 2009; 6(2):407-409. 
[11] Vasquez-montiel O, Horan NJ, Mara DD. Management of domestic wastewater for reuse in irrigation. Water Sci Technol 1996; 33(10-11):355-362.

[12] Zema DA, Bombino G, Andiloro S, Zimbone SM. Irrigation of energy crops with urban wastewater: Effects on biomass yields, soils and heating values. Agric Water Manag 2012; 115:55-65.

[13] Gupta SP, Gajender, Yadav RK, Magan S, Koushik P. Effect of irrigation schedules of domestic waste water on growth and yield of fodder sorghum. Indian J Small Ruminants 2015; 21(2):257-263.

[14] Bedbabis S, Trigui D, Ahmed CB, Clodoveo ML, Camposeo S, Vivaldi GA, Rouina BB. Long-term effects of irrigation with treated municipal wastewater on soil, yield and olive oil quality. Agric Water Manag 2015; 160:14-21.

[15] Matheyarasu R, Balaji S, Nanthi, SB, Ravi N. Impacts of abattoir waste water irrigation on soil fertility and productivity, irrigation and drainage-sustainable strategies and systems, Muhammad Salik Javaid, IntechOpen; 2015.

[16] Kekere O, Ajibade FA, Ologundudu F. Recycling of greywater for agricultural irrigation: panacea to household waste water management. UDS Int J Dev 2018; 5(2):38-51.

[17] Darch T, Dunn RM, Guy A, Hawkins JMB, Ash M, Frimpong KA, Blackwell MSA. Fertilizer produced from abattoir waste can contribute to phosphorus sustainability, and biofortify crops with minerals. Plos ONE 2019; 14(9):1-16.

[18] Nafaranda WD, Ajayi IE, Shawulu JC, Kawe MS, Omeiza GK, Sani NA, Padilla-Gasca E, López-López A, Gallardo-Valdez J. Evaluation of stability factors in the anaerobic treatment of slaughterhouse wastewater. J Bioremediat Biodegrad 2011; 2:1-5.

[19] Akange ET, Chaha JA, Odo JI. Impact of Wurukum abattoir effluent on river Benue Nigeria, using macroinvertebrates as bio-indicators. Int J Aquac 2016; 6 (22): $1-11$.

[20] Akanni A, Ogbiye A, Onakunle O. The Impact assessment of abattoir waste facility discharge on water in Osogbo, Nigeria. Cogent Eng 2019; 6:1:1-9.

[21] Elemile OO, Raphael DO, Omole DO, Oloruntoba EO, Ajayi EO, Ohwavborua NA. Assessment of the impact of abattoir effluent on the quality of groundwater in a residential area of Omu-Aran, Nigeria. Environ Sci Eur 2019; 31:16-26.

[22] Padilla-Gasca E, Lopez-Lopez A, Gallardo-Vaidez J. Evaluation of stability factor in the anaerobic treatment of slaughterhouse wastewater. $\mathbf{J}$ Bioremediat and Biodegrad 2011; 2:114.

[23] Kuyeli MS. Assessment of industrial effluent and their impact on water quality of stream in Biantyre, (M.sc thesis), UnimaZomba; 2007.

[24] Mittal GS. Treatment of wastewater from abattoir before land-application - a review. Bioresour Technol 2006; 97:1119-1135.

[25] Arvanitoyannis IS, Ladas D. Meat waste treatment methods and potential uses. Int J Food Sci Tech 2008; 43:543-559.

[26] Sangodoyin AY, Agbawhe MO. Environmental study on surface and ground water pollutants from abattoir effluents. Bioresour Technol 1992; 41:193200.

[27] Benka-Coker M, Ojior O. Effect of slaughterhouse wastes on the water quality of Ikpoba River, Nigeria. Bioresour Technol 1995; 52(1):5-12.

[28] Adelegan JA. Environmental policy and slaughter house waste in Nigeria. In: Proceedings of the 28th WEDC Conference Kolkata (Calcutta) India; 2002, p. 3-6.

[29] Omole DO, Longe EO. An assessment of the impact of abattoir effluents on River Illo, Otta, Nigeria. J Environ Sci Technol 2008; 1(2):56-64.

[30] Li CT, Huang CSWJS. Chemical/bio-fluidized bed treatment of slaughter house wastewater. J Environ Eng 1986; 112, 718 .

[31] Ruiz I, Veiga M, De Santiago P, Blazquez R. Treatment of slaughterhouse wastewater in a UASB reactor and an anaerobic filter. Bioresour Technol 1997; 60(3):251-258.

[32] Masse DI, Masse L. Treatment of slaughter house waste water in anaerobic sequencing batch reactor. Can J Civ Eng 2000; 42:131-137

[33] Reuter D, Edwards D, Wilhelm N. Temperate and tropical crops. In: Plant analysis: an interpretation manual, D. J. Reuter \& J. B. Robinson (Eds.), CSIRO Publishing: Melbourne; 1997, p. 83-284.

[34] Rivera F, Warren A, Curds CR, Robles E, Gutierrez A, Gallegos E, Calderón A. The application of the root zone method for the treatment and reuse of highstrength abattoir waste in Mexico. Water Sci Technol 1997; 35(5):271-278.

[35] Castrol E, Manas MP, Heras JDL. Effects of wastewater irrigation on soil properties and turf grass growth. Water Sci Technol 2011; 63(8):1678-1688.

[36] Sparling GP, Barton L, Duncan L, McGill A, Speir TW, Schipper LA, Van Schaik A. Nutrient leaching and changes in soil characteristics of four contrasting soils irrigated with secondary-treated municipal wastewater for four years. Soil Res 2006; 44(2):107-116.

[37] Roy M, Karmakar S, Debsarcar A. Application of rural slaughterhouse waste as an organic fertilizer for pot cultivation of solanaceous vegetables in India. Int $\mathbf{J}$ of Recycl Org Waste Agric 2013; 2(6):1-11.

[38] Toze S. Reuse of effluent water-benefits and risks. Agric Water Manag 2006; 80(1):147-159.

[39] Akpor OB, Muchie M. Environmental and public health implications of wastewater quality. Afr J Biotechnol 2011; 10 (13):2379-2387.

[40] Omole DO, Ogbiye AS. An evaluation of slaughterhouse wastes in South-West Nigeria (2013). American J Environ Prot 2013; 2(3):85-89.

[41] Hassan IA, Campbell C, Ademola AG. Effect of abattoir effluent on surrounding underground water quality: a case study of Governor Road Abattoir, Ikotun, Lagos State. J Adv Pharm Biol Chem 2014; 3(4):957-965.

[42] Bustillo-Lecompte C, Mehrvar M. Slaughterhouse wastewater: treatment, management and resource recovery. In: Physico-chemical wastewater treatment and resource recovery. INTECH Publishers 2017, p. 153-174. 
[43] Igbinosa IH, Uwidia IE. Effect of abattoir effluents on the physicochemical properties of a receiving watershed in an urban community. Ife J Sci 2018; 20(2):219-228.

[44] Chukwu O. Analysis of groundwater pollution from abattoir waste in Minna, Nigeria. Res J Dairy Sci 2008; 2(4):74-77.

[45] Kekere O, Ogunebanmi O, Eze CJ, Bulu YI, Kareem IA. Germination and seedling evaluation of pre-treated CanavaliamaIritima (AUBL.) seeds. Nigerian J Seed Sci 2019; 3(12):12-33.

[46] AOAC -Association of Official Analytical Chemists. Official methods of analysis (16 $6^{\text {th }}$ dn, No 1-2). Association of Official Analytical Chemists: Washington D.C. 1998.

[47] Matheyarasu R, Bolaji NS, Naidu R. Abattoir wastewater irrigation increases the availability of nutrients and influences on plant growth and development. Water Air Soil Poll 2016; 227:253-264.

[48] Nissim WG, Jerbi A, Lafleur B, Fluet R, Labrecque M. Willows for the treatment of municipal astewater: Performance under different irrigation rates. Ecol Eng $2015 ; 81: 395-404$.
[49] Juwarkar AS, Juwarkar A, Deshbratar PB, Bal AS Exploration of nutrient potential of domestic and sludge through and land application. In: RAPA Report 1990, p. 178- 201.

[50] Al-Jaloud AA, Hussian G, Al-Saati AJ, Karimulla S. Effect of wastewater irrigation on mineral composition of corn and sorghum plants in a pot experiment. J Plant Nutr 1995; 18:1677-1692.

[51] Fonseca AF, Melfi AJ, Montes CR. Maize growth and changes in soil fertility after irrigation with treated sewage effluent, plant dry matter yield and soil nitrogen and phosphorus availability. J Soil Sci 2005; 36:1965-1981

[52] Babyshakila P, Usha K. Effect of diluted effluents on soil properties and plant growth. J Adv Stud Biol 2009; 1(8):391-398.

[53] Achuba FI, Iserhienrhien LO. Effects of soil treatment with abattoir effluent on morphological and biochemical profiles of cowpea seedlings (Vigna unguiculata) grown in gasoline polluted soil. Ife J Sci 2018; 20(1): 51-59. 